\title{
РОЗВИТОК КОМУНІКАТИВНИХ ЗДІБНОСТЕЙ УЧНІВ: ТЕОРЕТИЧНИЙ АНАЛІЗ
}

Theory, Experience, Problems. Kyiv; Vinnytsia: DOV Vinnytsia. part. 2,pp. 202-208. [in Ukrainian].

5. Kanivets, O. (2010). Osoblyvosti riznorivnevoi pidhotovky fakhivtsiv u Velykobrytanii [Features of Specialists Multi-Level Training in Great Britain]. Bulletin of the Book Chamber. No. 3. pp. 49-52. [in Ukrainian].

6. Mahrlamova, K. (2018). Analiz systemy kvalifikatsii maibutnikh likariv u Velykii Brytanii [The Analysis of the Qualificational System of Future Doctors in the UK]. Youth \& Market. Vol. 6 (161) pp. 70-76. [in Ukrainian].

7. Osvita u Velykobrytanii [Education in the UK]. Available at: http://www.ukvisas.com.ua/indexr_39.html. [in Ukrainian].

8. Osobennosti obrazovaniya $v$ Anglii [Features of Education in England]. Available at: http:// www.keytosuccess.ru/education-uk/osobennostiangliyskogo-obrazovaniya.html. [in Russian].
9. Systema osvity Velykoi Brytanii [British Education System]. Available at: http://www.osvita.org.ua/abroad/ edusystem/gbr. [in Ukrainian].

10. Abdon, B., Raab, R. \& Ninomiya, S. (2008). ELearning for International Agriculture Development: Dealing with Challenges. Japan International Journal of Education and Development using Information and Communication Technology. Vol. 4. Issue 1, pp. 80-94. [in English].

11. Cook, J.F. (1998). Distance Education for Agriculture and Rural Development: The Third Wave. The University of Reading, 53 p. [in English].

12. Leary, J. \& Berge, Z. (2006). Trends and Challenges of E-Learning in National and International Agricultural Development. International Journal of Education and Development using ICT. Vol. 2. No. 2, pp.51-59. [in English].

Стаття надійшла до редакції 08.01.2019

УДК 159.923 .38

DOI:

Анжела Король, кандидат педагогічних наук, доцент кафедри педагогіки Криворізького державного педагогічного університету

\section{РОЗВИТОК КОМУНІКАТИВНИХ ЗДІБНОСТЕЙ УЧНІВ: ТЕОРЕТИЧНИЙ АНАЛІЗ}

У статті розкрито актуальність та важливість проблеми розвитку комунікативних здібностей учнів сучасної школи із точки зору останніх державних документів. Проаналізовано психолого-педагогічні дослідження сучасних учених з даної проблеми, трактування понять “здібності”, “комунікативні здібності”, "комунікачія”, “спілкування”. Розглядається структура здібностей і комунікативних здібностей, спечифіка комунікативного аспекту спілкування, подані педагогічні умови ефективного розвитку комунікативних здібностей учнів.

Ключові слова: здібності; комунікативні здібності; комунікація; спілкування; педагогічні умови.

Jim. 17.

Anzhela Korol, Ph.D.(Pedagogy), Associate Professor of the Pedagogy Department, Kryviy Rih State Pedagogical University

\section{DEVELOPMENT OF COMMUNICATIVE SKILLS OF STUDENTS: THEORETICALANALYSIS}

The problem of development of communicative abilities of students is relevant and promising. Communication between the teacher and the students, as well as between the students themselves, is so problematic that its decision depends largely on many conditions: the relationship between members of the classroom team; the influence of the teaching staff on the life and activities of the class team; the attitude of the class team to the teachers teaching in this class; the attitude of the subject teacher to students with different abilities to study and perception of the subject (physics, mathematics, history, etc.); the ability of the student to express their views on the material that is offered to them by the teacher; the student's ability to correct analyzing of the education material presented by the teacher; the student's ability to give the correct answer to the question of his friend about why he did not understand the education material offered by the teacher in a proper way, etc.

The article discusses the interpretation of the concepts "ability", "communication skills", "communication" from different points of view. As the analysis of the literature has shown, there are several types of classifications of types of abilities. For example: according to the content and nature of the activity, the abilities are divided into general and special. According to the level of use-for educational and creative. There are also theoretical and practical abilities.

Keywords: abilities; communication skills; communication, pedagogical conditions of the development of communication skills; a structure of communication skills; dependence of communication skills on the development of the students 'personality. 
життя у світлі різноманітних зв'язків, відносин, комунікативних можливостей. Про це свідчать прийняті в останні роки державні нормативні документи: "Національна стратегія розвитку освіти в Україні на 2012 - 2021 рр.”(2012), “Проект Концепції розвитку освіти України на період 2015 - 2025 рр.” (2014), Проект закону України “Про освіту” (2016), в яких так чи інакше визначається формування в учнівської молоді уміння міжособистісного спілкування, комунікативних відносин.

В психолого-педагогічній літературі можна зустріти ствердження про те, що поняття “комунікація" і “спілкування" тотожні (Н. Вітюк, А. Коваленко, Л. Коломинський тощо). Це не зовсім так. Часто під спілкуванням розуміють процес взаємодії між двома чи кількома особами за допомогою вербальних і невербальних засобів, спрямований на обмін особистісними установками, поглядами, враженнями, думками та враженнями, встановлення та розвитку контактів між ними. Комунікацію розуміють як процес обміну різною інформацією, спілкування із метою передавання та одержання інформації. Тому вважається, що ці два поняття близькі між собою, але поняття “комунікація" ширше по об'єму.

3 поняттям комунікації та спілкування тісно пов'язані такі поняття як здібності, комунікативні здібності. Як вважають О. Леонтьєв, С. Рубінштейн, Б. Теплов та інші вчені, процес розвитку здібностей людини є процес розвиту людини. Комунікативні здібності сприяють досягненню високих результатів у комунікативній діяльності. На думку ряду авторів (Г. Данченко, Н. Вітюк, М. Заброцького та інших), комунікативні здібності сприяють більш ефективної передачі інформації, встановленню контактів, розумінню комунікативної ситуації, спілкуванню та взаємодії з іншими людьми. Вони є передумовою опанування молоддю знань, умінь та навичок, які обумовлюють успішність комунікативної діяльності.

Аналіз останніх досліджень і публікацій. Проблема розвитку комунікативних здібностей у психолого-педагогічної літературі не нова. Тією чи іншою мірою даною проблемою займалися такі вчені, як Н. Волкова, І. Зимня, О. Леонтьєв, Б. Ломов, Р. Немов, Ю. Пассов, В. Семиченко, В. Скалкін, Б. Теплов та ін. Наприклад, загальнопсихологічні основи теорії здібностей вивчали В. Дружинін, О. Леонтьєв, Б. Теплов та ін.Н. Вініченко,Ж. Глозман,Л. Засекіна, С. Рубінштейн досліджували проблеми закономірності розвитку, змісту, структури комунікативних здібностей, їх сутнісні характеристики. А. Бодальов, Р. Немов розглядають поняття “комунікативні здібності”, їх роль у житті людини. Н. Кузьміна, О. Леонтьєв, К. Платонов, К. Роджер розглядають комунікативні здібності як чинник успішної самореалізації особистості. Н. Вітюк, Н. Волкова, Г. Данченко, Н. Завіниченко, К. Соснова розглядають комунікативні здібності як складову комунікативної компетенції, а також розвиток комунікативних здібностей учнів у навчальному процесі.

Незважаючи на те, що проблема розвитку комунікативних здібностей учнів знайшла своє відбиття у багатьох наукових працях, на наш погляд окремі аспекти розвитку комунікативних здібностей школярів залишаються ще недостатньо вивченими.

Мета статті полягає в аналізі трактування понять “здібності”, “комунікативні здібності”, висвітлення теоретичних проблем розвитку комунікативних здібностей учнів.

Виклад основного матеріалу. Огляд психолого-педагогічної літератури показав, що існує багато трактувань понять “здібності", “комунікативні здібності”. Наведемо деякі трактування даних понять.

В "Українському педагогічному словнику" говориться, що “Здібності-це стійкі індивідуальні психічні особливості людини, які є необхідною внутрішньою умовою їі успішної діяльності. Вони виявляються у тому, як людина вчиться, одержує певні знання, уміння й навички, освоює певні галузі діяльності, включається у творче життя суспільства" $[6,135]$.

О. Винославська під здібностями розуміє “індивідуально-психологічні особливості людини, які відповідають умовам успішного виконання тієї чи іншої діяльності, а саме - набуття знань, умінь і навичок; використання їх у практиці” [2, 212].

Л. Столяренко і С. Самигін відзначають, що “здібності - це індивідуально-психологічні особливості особистості, що забезпечують успіх у діяльності, у спілкуванні й легкості в оволодінні ними" [16, 305].

Аналіз літератури показав, що існує декілька класифікацій видів здібностей, в основі яких покладені різні ознаки. Наприклад, за змістом і характером діяльності здібності поділяють на загальні й спеціальні. За рівнем застосування на учбові і творчі. Розрізняють також теоретичні й практичні здібності [1].

Згідно $з$ даною класифікацією загальні здібності забезпечують успішне виконання різних видів діяльності (таких, які вимагають прояву високорозвиненого інтелекту і напруженої 


\section{РОЗВИТОК КОМУНІКАТИВНИХ ЗДІБНОСТЕЙ УЧНІВ: ТЕОРЕТИЧНИЙ АНАЛІЗ}

розумової діяльності) і дають можливість успішно навчатись. Спеціальні здібності проявляються в певній сфері діяльності учнів - музиці, математиці, малюванні, спорті, техніці тощо. У одного учня можливе поєднання як загальних, так i спеціальних здібностей.

Учбові здібності проявляються як швидке $\mathrm{i}$ якісне засвоєння знань, вироблення вмінь, однак не передбачають оригінальності продуктів діяльності. Творчі здібності виявляються через створення учнями нестандартних, оригінальних продуктів діяльності. Для досягнення рівня творчих здібностей учень спочатку виробляє учбові здібності.

Теоретичні здібності пов'язані $з$ наявністю в учнів теоретичного, абстрактного мислення. Практичні здібності передбачають не тільки наявність, але і переважання в діяльності практичного, наочно-дійового мислення.

Кожна здібність має свою структуру в залежності від розвитку особистості. У літературі виділяють два види розвитку здібностей: репродуктивний та творчий. Також в структурі здібностей розрізняють провідні й допоміжні властивості. Наприклад, провідними властивостями в літературних здібностях $є$ особливості творчої уяви та мислення, яскраві наочні образи пам'яті, розвиток естетичних почуттів, почуття мови; в математичних - уміння узагальнювати, гнучкість процесів мислення, легкий перехід від прямого до зворотного ходу думки; у художних - особливості творчої уяви і мислення, властивості зорової пам'яті, розвиток естетичних почуттів та ін. [13].

Розглянемо поняття “комунікативні здібності”. В “Енциклопедичному словнику” дається таке визначення даного поняття: це “індивідуальнопсихологічні особливості особистості, що забезпечують ефективну взаємодію та адекватне взаєморозуміння між людьми в процесі навчання або виконання спільної діяльності. Комунікативні здібності дозволяють успішно вступати в контакт з іншими людьми, здійснювати комунікативну, організаторську, педагогічну та інші види діяльності” $[14,300]$.

У “Словнику термінів 3 психологічного консультування" говориться: "Комунікативні здібності - здібності людини, які виявляються в ііi спілкуванні з людьми. Вони включають в себе вміння слухати і розуміти людей, впливати на них, установлювати 3 ними гарні особисті та ділові взаємини" [15].

Н. Вітюк вважає, що комунікативні здібності - це “комплекс індивідуально-психологічних особливостей, що забезпечують здатність індивіда до активного й ефективного спілкування, передачі й адекватного сприймання інформації, організації взаємодії 3 іншими людьми, правильного розуміння себе і своєї поведінки та партнерів у спілкуванні, їх поведінки, що є необхідними умовами успішної життєдіяльності людини" $[4,165]$.

Р. Немов стверджує, що “комунікативні здібності - це знання, уміння й навички, пов'язані 3 процесом спілкування людей. Вони містять у собі вміння слухати й розуміти людину, установлювати 3 нею гарні особистісні й ділові взаємини, чинити на неїпсихологічний вплив" $[10,139]$.

А. Нісімчук і О. Падалка надають таке визначення: "Комунікативні здібності - це риси особистості, яка керується певними мотивами в реалізації цілей при здійсненні контактів, спілкуванні, обміні інформацією з іншими людьми" $[11,87]$.

Відсутність у літератури єдиного підходу до трактовки поняття “комунікативні здібності”, на наш погляд, породжено його термінологічною невизначеністю.

Сучасні вчені класифікують комунікативні здібності на декілька груп: 1) загальні й спеціальні; 2) вербальні й невербальні; 3) спеціально-важливі й універсально-важливі; 4) стратегічні й тактичні $[12,86]$. Багато $з$ них (Н. Вітюк, Н. Волкова, Г. Данченко, Н. Завіниченко, Ю. Якимчук) відносять комунікативні здібності до спеціальних і вважають, що вони $є$ як умовою, так і результатом ефективного спілкування, сприяють активною взаємодією з іншими особами, формуванню комунікативних знань та умінь, передачі різної інформації.

Аналіз психолого-педагогічної літератури показав, що відсутність єдиного підходу до визначення поняття “комунікативні здібності” веде до відсутності єдиного підходу й до визначення структури комунікативних здібностей. Відповідно до того, які критерії поклав дослідник в основу при розгляді комунікативних здібностей, такі компоненті він вкладає i до структурі комунікативних здібностей.

Так, Г. Андрєєва, А. Батаршов, В. Волкова включають до структури комунікативних здібностей комунікативній, інтерактивній і перцептивній компоненти; Е. Голубєва псіхофізіологнічний, психологічний та соціальнопсихологічний; А. Кідрон - сукупність особистісного, поведінкового і пізнавальнооцінювального компонентів; Н. Воробйова пропонує виділити у структурі продуктивність i варіативність спілкування, прояв позитивних емоцій, довіру людей, спостережливість, особливості мовлення та голосу, інтелектуальні 
якості, самовитримку, емпатичне відношення, толерантність, точність сприйняття, здатність отримувати задоволення від спілкування, комунікативний етикет; M. Скрипко доброзичливість, емпатію, самоконтроль уконфлікті, гнучкість; Ю. Смельянов, І. Зотова, С. Петрушін - когнітивний, вольовий, особистісний та інструментальний; П. Чарченко - стратегічні та тактичні блоки, які у взаємодії описують процес комунікації [17, 316-318].

Поняття “комунікативні здібності” включає до себе таке поняття як “комунікація”. У Вікіпедії дається наступне визначення цього поняття: “Комунікація (від лат. communicatio - єдність, передача, з'єднання, пов'язаного з дієсловом лат. communico - роблю спільним, повідомляю, з'єдную, похідним від лат. communis - спільний) - це процес обміну інформацією (фактами, ідеями, поглядами, емоціями тощо) між двома, або більш особами, спілкування за допомогою вербальних і невербальних засобів із метою передавання та одержання інформації' [3].

Н. Волкова вважає, що “комунікація є формою зв’язку, процесом повідомлення інформації за допомогою технічних засобів, актів спілкування між двома або більше індивідами, процесом передачі інформаційного, емоційного або інтелектуального змісту" [5, 420].

Л. Коломинський стверджує, що комунікація - “це спілкування, передача інформації, думок, почуттів, волевиявлення людини мовними способами. Комунікація $є$ складним процесом взаємодії між людьми, що полягає в обміні інформацією, а також у прийнятті й розумінні партнерами один одного" $[8,32]$.

В "Українському педагогічному словнику" пишеться, що “комунікація - акт спілкування, зв'язок між двома або більше індивідами, що базується на взаєморозумінні” $[6,174]$.

Аналіз науковій літератури показав, що поняття “комунікація” досить часто ототожнюють 3 поняттям “спілкування” і вважають їх синонімами. Але це не зовсім так. Вітчизняні вчені розрізняють ці поняття. Наприклад, М. Каган поділив терміни “комунікація” і “спілкування”: а) спілкування має практичний i духовний характер, тоді як комунікація - це суто інформаційний процес; б) спілкування - це міжсуб'єктна взаємодія і структура його діалогічна, тоді як комунікація це інформаційний зв'язок суб'єкта з будь-яким об'єктом [7, 186]. Також вважається, що спілкування є цілеспрямованим, соціально зумовленим процесом обміну інформацією між людьми в різних сферах трудової, пізнавальної, творчої діяльності і через нього відбувається навчання і виховання людини, засвоєння нею різних форм соціального досвіду, норм і правил поведінки, звичаїв і традицій.

На думку С. Знаменської, специфіка комунікативного аспекту спілкування полягає в тому, що: спілкування - це активний обмін інформацією між особами, у ході якого предмет спілкування досягається спільно; обмін інформацією передбачає психологічний вплив суб'єктів на поведінку партнера 3 метою зміни; комунікативний вплив можливий лише тоді, коли суб'єкти володіють єдиною або подібною системою кодування (тобто говорять однією мовою); для спілкування характерні комунікативні бар'єри, що мають соціальний або психологічний характер [7, 186].

Розвитку комунікативних здібностей учнів буде проходити більш ефективно, якщо дотримуватися наступних педагогічних умов:

- врахування індивідуальності кожного учня;

- комунікативна спрямованість процесу навчання;

- гуманістична спрямованість процесу навчання;

- створення освітнього комунікативного середовища на засадах розвивального навчання;

- поетапність розвитку комунікативних здібностей;

- забезпеченість комунікативної насиченості індивідуальної і групової діяльності учнів;

- володіння кожним учнем інформацією про якісний рівень власних комунікативних здібностей [9, 101].

Висновки і перспективи подальших досліджень. Аналіз літератури показав, що вивчення розвитку комунікативних здібностей учнів $\epsilon$ одним із важливих напрямків у дослідженнях проблем сучасної школи. Відсутність єдиного підходу при вивченні комунікативних здібностей привело до того, що існує дуже багато трактувань даного поняття. У свою чергу, які критерії дослідник поклав в основу при розгляді комунікативних здібностей, такі компоненті він вкладає і до їх структурі, що веде до труднощів в інтерпретації і зрівнянні результатів різних досліджень по даної теми. Комунікативні здібності учнів є динамічною системою, яка виявляється уздатності до спілкування, організації взаємодії з іншими особами (вчителями, батьками, друзями та однокласниками), передачі та сприймання різної інформації.

Дослідження охоплює лише частину порушеної проблеми, більш глибокого вивчення потребують вивчення впливу дорослих (батьків, вчителів) на розвиток комунікативних здібностей учнів, 
виявлення та створення для цього оптимальних педагогічних умов.

\section{ЛІТЕРАТУРА}

1. Види здібностей та рівні їх прояву: URL: http:/ pidruchniki.com/16381204/psihologiya/ vidi zdibnosey rivni proyavu.

2. Винославська О. В.:Психологія: навч. посіб. Київ: Інкос, $-2005 .-417 \mathrm{c}$

3. Вікіреdia. URL: https://wikipedia/org/wiki/ $\% \mathrm{DO} \% \mathrm{~A} 2 \% \mathrm{DO} \% \mathrm{~B} 5 \% \mathrm{DO} \% \mathrm{BO} \% \mathrm{D} 1 \% 82 \% \mathrm{D} 1 \% 80$.

4. Вітюк Н. Р. Основні психологічні підходи до визначення категорії "комунікативні здібності особистості”. Вісник прикарпатського університету: Філософські і психологічні науки:зб. наук. праць, ІваноФранківськ: Плай, -2002. - Вип. 3. С. 158 -167.

5. Волкова Н. П. Професійно-педагогічна комунікація: навч. посіб. Київ: ВЦ “Академія”, - 2006. $256 \mathrm{c}$

6. Гончаренко С. У. Український педагогічний словник. Київ: Либідь, - 1997. - 376 с.

7. Ковальчук Н. П. Комунікативна культура як умова вдосконалення професійної підготовки майбутніх фахівців у ВНЗ. Наукові записки Національного університету “Острозька академія". Серія “Філологічна”. Волинь, -2015. - Вип. 57. С. 185 - 187.

8. Коломинский Л. Я. Психология общения: учебн. пособ. Москва: Мысль, - 1974. - 221 с

9. Кузьменко В., Міськова Г. Теоретичний аналіз проблеми розвитку комунікативних здібностей підлітків. Міжнародний науковий форум: соціологія, психологія, педагогіка, менеджмент. Київ, - 2012. - Вип. 10. С. 95 103.

10. Немов Р. С. Психология: учебн. пособ. Москва Владос, - 2002. - Кн.1. 688 с.

11. Нісімчук А. С., О. С. Падалка: Сучасні педагогічні технології : навч. посіб. Київ: Просвіта, $-2000 .-368$ с.

12. Панасенко Е., Черепова Ю. Розвиток комунікативних здібностей майбутніх учителівфілологів: психолого-педагогічний аспект. Професіоналізм педагога: теоретичні й методичні аспекти. Слов'янськ, -2017. - Вип. 5. Ч. 2. С. 81 - 91.

13. Поняття про здібності. Структура і види здібностей: URL: http://www.ebk.net.ua/Book/ psichology/vinoslavska psichologiya/nart4/4501.htm.

14. Психология общения. Энциклопедический словарь / под общ. ред. А. А. Бодалева. Москва: Когнито-Центр, -2011. -549 с.

15. Словарь терминов по психологическому консультированию: URL: http://psyhological conseling.academic.ru/96.

16. Столяренко Л. Д., Самыгин С. И.: Психология и педагогика в вопросах и ответах: учебн. пособ. Ростовна-Дону: Феникс, $-2000 .-576$ с.

17. Якимчук Ю. В. Розвиток когніктивного компонента комунікативних здібностей у студентів вищих навчальних закладів. Психологічні науки. Київ, - 2010. - Вісник національної академії Державної прикордонної служби України. № 4 С. $68-73$.

Молодь і ринок №2 (169), 2019

\section{REFERENCES}

1. Vydy zdibnosei ta rivni yikh proiavu [Types of abilities and levels of their manifestation]. Available at:http:/pidruchniki.com/16381204/psihologiya/ vidi zdibnosey rivni proyavu. [in Ukrainian].

2. Vynoslavska, O. V. (2005). Psykholohiia: navch. posib. [Psychology: a tutorial]. Kyiv: Incos, 417 p. [in Ukrainian].

3. Wikipedia. Available at: https://wikipedia/org/wiki/ $\% \mathrm{DO} \% \mathrm{~A} 2 \% \mathrm{DO} \% \mathrm{~B} 5 \% \mathrm{DO} \% \mathrm{BO} \% \mathrm{D} 1 \% 82 \% \mathrm{D} 1 \% 80$. [in Ukrainian].

4. Vitiuk, N. R. (2002). Osnovni psykholohichni pidkhody do vyznachennia katehorii "komunikatyvni zdibnosti osobystosti" [Basic psychological approaches to the definition of the category of "communicative personality abilities"]. Journal of Carpathian University: Philosophical and psychological sciences: a collection of scientific works. Ivano-Frankivsk: Play, vol. 3, pp. 158 167. [in Ukrainian].

5. Volkova, N. P. (2006). Profesiino-pedahohichna komunikatsiia: navch. posib. [Professional pedagogical communication: a tutorial]. Kyiv: VT "Akademiia", 256 p. [in Ukrainian].

6. Honcharenko, S. U. (1997). Ukrainskyi pedahohichnyi slovnyk [Ukrainian Pedagogical Dictionary]. Kyiv: Lybid, 376 p. [in Ukrainian].

7. Kovalchuk, N. P. (2015). Komunikatyvna kultura yak umova vdoskonalennia profesiinoi pidhotovky maibutnikh fakhivtsiv u VNZ [Communicative culture as a condition for improving the professional training of future specialists in higher educational institutions]. Scientific notes of the National University "Ostroh Academy". Series "Philological". Volin, vol. 57, pp. 185-187. [in Ukrainian].

8. Kolomynskyi, L. Ya. (1974). Psykholohyia obshchenyia: uchebn. posob. [Psychology of communication: study guide]. Moskov: Thought, $221 \mathrm{p}$. [in Russian].

9. Kuzmenko, V. \& Miskova, H. (2012). Teoretychnyi analiz problemy rozvytku komunikatyvnykh zdibnostei pidlitkiv [Theoretical analysis of the problem of development of communicative abilities of adolescents]. International scientific forum: sociology, psychology, pedagogy, management. Kyiv: vol. 10, pp. 95-103. [in Ukrainian].

10. Nemov, R. S. (2002). Psykholohyia: uchebn. posob. [Psychology: a tutorial]. Moskov: Vlados, b. 1.688 p. [in Russian].

11. Nisimchuk, A. S. \& Padalka, O. S. (2000). Suchasni pedahohichni tekhnolohii: navch. posib. [Modern Pedagogical Technologies: a tutorial]. Kyiv: Prosvita, 368 p. [in Ukrainian].

12. Panasenko, E. \& Cherepova, Yu. (2017). Rozvytok komunikatyvnykh zdibnostei maibutnikh uchytelivfilolohiv: psykholoho-pedahohichnyi aspekt [Development of communicative abilities of future teachers of philology: psychological and pedagogical aspect]. Teacher's Professionalism: Theoretical Methodical Aspects. Sloviansk: vol. 5, part. 2, pp. 81-91. [in Ukrainian].

13. Poniattia pro zdibnosti. Struktura i vydy zdibnostei 
[The concept of ability. Structure and types of abilities]. available at: http://www.ebk.net.ua/Book/psichology/ vinoslavska psichologiya/nart4/4501.htm. [in Ukrainian].

14. Psykholohyia obshchenyia. Entsyklopedycheskyi slovar (2011). [Psychology of communication. Encyclopedic Dictionary]. Moskov: Kohnyto-Centre, 549 p. [in Russian].

15. Slovar termynov po psykholohycheskomu konsultyrovanyiu [Psychological counseling vocabulary]. Available at: http://psyhological_conseling.academic.ru/ 96. [in Russian].

16. Stoliarenko, L. D. \& Samyhyn, S. Y. (2000).
Psykholohyia y pedahohyka $v$ voprosakh y otvetakh: uchebn. posob. [Psychology and pedagogy in questions and answers: study guide]. Rostov-na-Donu: Fenyks 576 p. [in Russian].

17. Iakymchuk, Yu. V. (2010). Rozvytok kohniktyvnoho komponenta komunikatyvnykh zdibnostei u studentiv vyshchykh navchalnykh zakladiv [Development of cognitive component of communicative abilities in students of higher educational institutions]. Journal of the National Academy of the State Border Guard Service of Ukraine. Series: Psychological Sciences. Kyiv: vol. 4, pp. 68-73. [in Ukrainian].

Стаття надійшла до редакції 24.01.2019

УДК 378.011

DOI:

Ольга Потапчук, кандидат педагогічних наук, доиент кафедри комп'ютерних технологій Тернопільського національного педагогічного університету імені Володимира Гнатюка

\section{ОСОБЛИВОСТІ ПРОЕКТНОЇ ДІЯЛЬНОСТІ СТУДЕНТІВ В НАВЧАЛЬНОМУ ПРОЦЕСІ ЗАКЛАДІВ ВИЩОЇ ОСВІТИ}

У статті розкрито актуальність та особливості застосування в навчальному процесі закладів вищої освіти методу проектів, їх вплив на формування професійних компетентностей майбутніх фахівців. Виділено основні здібності та спрямування студентів, які формуються під час навчання із застосуванням їх проектної діяльності, запропоновано основні вимоги до навчальних проектів. Виділено негативні фактори, наявність яких знижує ефективність методу проектів в процесі професійної підготовки студентів до їх професійної діяльності (особистісний, професійний, організачійний). Виділено основні три етапи управління проектною діяльністю: підготовки, виконання та реалізації. Встановлено, щуо застосування методу проектів в навчальному процесі закладів вищзої освіти дають можливість вирішення ряду питань: підвищення активності, ініціативи, творчого пошуку, налагодження комунікативності в студентському колективі, вирішення психологічних проблем, особистісних стосунків між суб 'єктами проекту, пошук нових лідерів групи, виховання особистісних якостей студентів (взаємодопомога, взаємодія, самовдосконалення, самореалізаџія тощо).

Ключові слова: проектна діяльність; навчальний процес; метод проектів; освітні технологї̈; професійні компетентності.

Табл. 1. Лім. 4.

Olha Potapchuk, Ph.D.(Pedagogy), Associate Professor of the Computer Technologies Department Ternopil Volodymyr Hnatyuk National Pedagogical University

\section{FEATURES OF PROJECT ACTIVITY OF STUDENTS IN THE EDUCATIONAL PROCESS OF HIGHER EDUCATION INSTITUTIONS}

The article deals with the relevance and peculiarities of application of the project method in the educational process of institutions of higher education, their influence on the formation of professional competences of future specialists. The basic abilities and direction of students, which are formed during studying with application of their project activity, are given, the main requirements for educational projects are offered. The negative factors are identified, the presence of which reduces the effectiveness of the method of projects in the process of professional training of students to their professional activities (personal, professional, organizational). The main three stages of project activity management: preparation, and implementation are allocated. It was established that the application of the method of projects in the educational process of higher education institutions provides an opportunity to solve a number of issues: increase of activity, initiative, creative search, establishment of communicative skills in the student collective, solving psychological problems, personal relationships between subjects participating in project, finding the new group leaders, education of personal qualities of students (mutual assistance, interaction, self-improvement, self-realization, etc.).

Keywords: the project activity; an educational process; a project method; educational technologies; professional competencies.

$\Pi$

остановка проблеми. Сучасний стан розвитку вищої освіти ставить нові вимоги, які повинні відповідати міжнародним стандартам вищої освіти. Освіта $\epsilon$ основою розвитку не лише особистості, а й суспільства, держави, нації. Мета державної 